\title{
Colorectal Cancer in Different Age Groups in a Tertiary Hospital in Nepal
}

\author{
Nandu Silwal Poudyal, ${ }^{1}$ Sitaram Chaudhary, ${ }^{1}$ Bhupendra Kumar Basnet, ${ }^{1}$ Bidhan Nidhi Paudel, ${ }^{1}$ Barun Shrestha, ${ }^{1}$ Amrendra \\ Kumar Mandal,' Mukesh Sharma Paudel' \\ 'Gastroenterology Unit, Department of Medicine, NAMS, Bir Hospital, Kathmandu, Nepal.
}

\section{ABSTRACT}

Introduction: Some studies have suggested that colorectal cancer at a younger age had distinct biological characteristics: different clinical presentations, more advanced stage at time of diagnosis and poorly differentiated carcinoma. The aim of the study is to analyze clinical and histopathological differences between younger ( $\leq 40$ years of age) and older ( $>40$ years of age) colorectal cancer patients.

Methods: A cross-sectional analysis was conducted amongst the colorectal cancer patients who visited Bir Hospital between July 2015 and April 2017. All colonoscopically diagnosed and histopathologically proven cases of colon cancer were included. Chi-square test and independent $\mathrm{t}$ - test was performed to analyze the difference between clinical presentations and histopathological findings among two groups of patients and $\mathrm{P}$ value of $<0.05$ was considered as significant.

Results: Thirty younger patients and thirty older patients were enrolled without any differences in gender proportion. There were no statistical differences between clinical presentation and histological grade and type in younger and older patients. The younger patients had more complaints of altered bowel habit $(\mathrm{P}<0.001)$ while older patients mostly presented with per rectal bleeding $(\mathrm{P}<0.008)$.

Conclusions: In this study, colorectal cancer at younger ages showed similar characteristics to those of older patients except altered bowel habit was more common in younger patients while per rectal bleeding was more common in older patients. Although colorectal cancer incidence increases with age, younger patients with altered bowel habits, weight loss, anemia and anorexia should also be given due medical attention and undergo evaluation promptly.

Keywords: carcinoma; colon; per rectal bleeding; younger group.

\section{INTRODUCTION}

Colorectal carcinoma (CRC) is one of the most common cancers diagnosed worldwide, with over 1.2 million new cases diagnosed each year. ${ }^{1}$ Despite improvements in screening for early diagnosis, colorectal cancer remains one of the biggest cancer killers in the world. It is documented as the fourth most frequent cancer in men and third in women. ${ }^{2}$ It is also one of the most common cancers in Nepal. ${ }^{3}$

Age is considered a major risk factor for colon cancer. Although CRC occurs predominantly in older people, it does affect young adults with a high incidence of up to $28 \%$ and this incidence is higher in Asia. ${ }^{4}$

This study is designed to compare the sites of primary tumor, clinical presentations and histopathological types of CRC in younger ( $\leq 40$ years of age) and older ( $>40$ years of age) patients at Bir Hospital. A demonstration that colorectal cancer is more frequent than commonly

Correspondence: Dr. Nandu Silwal Poudyal, Gastroenterology Unit, Department of Medicine, NAMS, Bir Hospital, Kathmandu, Nepal. Email: nandupoudyal@gmail.com, Phone: +977-9851197723. 
assumed might lead to a reappraisal of clinical practice, medical priorities and resource allocation.

\section{METHODS}

A cross-sectional study was conducted at department of gastroenterology of Bir Hospital from July 2015 to April 2017. The ethical approval was taken from Institutional Review Board of NAMS and consent was taken from each patient before enrollment. The inclusion criteria of this study were all colonoscopically diagnosed and histopathologically proven cases of colon cancer in Bir Hospital and exclusion criteria were all other diagnosis than CRC in histological biopsy and if patients do not give consent. Sampling was done and the sample size was calculated using following formula,

$\mathrm{Za}=1.96$ at $95 \%$ confidence level

$\mathrm{Zb}=0.84$ at $80 \%$ power

$\mathrm{P}_{1}=0.71$ in $>40$ years age group

$P_{2}=0.29$ in $<40$ years age group ${ }^{5}$

$\mathrm{P}=\left(\mathrm{P}_{1}+\mathrm{P}_{2}\right) / 2$

$\mathrm{n}=\left[\frac{\mathrm{z}_{\alpha} \sqrt{2 p(1-p)}+\mathrm{z}_{\beta} \sqrt{p_{1}\left(1-p_{1}\right)+p_{2}\left(1-p_{2}\right)}}{\left(p_{1}-p_{2}\right)}\right]^{2}$

Using formula the sample size is $n=29$ in each group assuming that there will be higher prevalence among $>40$ group. Convenience sampling was taken. Data collecting consists of demographic aspects, gender, clinical aspects (chief complaints, duration of symptoms until diagnosis was established, family history of cancer, previous history of neoplastic disease), tumor location (caecum, ascending colon, hepatic flexure, transverse colon, splenic flexure, descending colon, rectosigmoid junction, rectum), differentiation grade ( poorly, moderate and well differentiated), histologic types (adenocarcinoma, mucinous carcinoma, or signet ring cell carcinoma) and laboratory data (hemoglobin, total count, platelets and CEA at time of diagnosis). Independent $t$ test and chi-square were used to compare the results of various parameters among the studied patients. Values were expressed as mean \pm SD, a $95 \%$ confidence interval was taken and $P$ values of $<0.05$ was considered to be statistically significant. SPSS version 17 was used.

\section{RESULTS}

Sixty patients were enrolled. Thirty patients were $\leq 40$ years (younger patients) and 30 patients were $>40$ years (older patients). Number of male patients in young patients group were $14(46.7 \%)$ and female were $16(53.3 \%)$, while in older patients group male were $18(60 \%)$ and female were $12(40 \%)$. There is no significant difference of male and female $p$ proportion between these two groups $(P=0.301)$ (Table 1$)$.

\begin{tabular}{|c|c|c|c|c|}
\hline \multicolumn{3}{|c|}{$\begin{array}{l}\text { Table 1. Differences between } \\
\text { patients based on sex. }\end{array}$} & \multirow{3}{*}{\multicolumn{2}{|c|}{$\begin{array}{c}\text { younger and } 0 \\
\chi 2 \quad P \text { value }\end{array}$}} \\
\hline \multirow{2}{*}{ Sex } & \multicolumn{2}{|l|}{ Group } & & \\
\hline & $\leq 40$ years & $>40$ years & & \\
\hline Female & 12 (40\%) & $16(53.3 \%)$ & \multirow{2}{*}{1.071} & \multirow{2}{*}{0.301} \\
\hline Male & $18(60 \%)$ & $14(46.7)$ & & \\
\hline
\end{tabular}

Table 2. Comparison of patient's chief complaints.

\begin{tabular}{|lllll|}
\hline Symptoms & $\begin{array}{l}\text { Group } \\
\leq \mathbf{4 0}\end{array}$ & $>\mathbf{4 0}$ & $\chi \mathbf{2}$ & P value \\
Abdominal & $26(86.7 \%)$ & $24(80.0 \%)$ & 0.48 & 0.488 \\
pain & $13(43.3 \%)$ & $23(76.7 \%)$ & 6.94 & 0.008 \\
$\begin{array}{l}\text { PR Bleeding } \\
\text { Abdominal }\end{array}$ & $4(13.3 \%)$ & $2(6.7 \%)$ & 0.185 & 0.667 \\
$\begin{array}{l}\text { mass } \\
\text { Weight loss }\end{array}$ & $23(76.7 \%)$ & $21(70.0 \%$ & 0.341 & 0.559 \\
$\begin{array}{l}\text { Anorexia } \\
\text { Altered bowel } \\
\text { habit }\end{array}$ & $20(66.7 \%$ & $21(70.0 \%)$ & 0.077 & 0.781 \\
\hline
\end{tabular}

Characteristic clinical symptoms in younger group were abdominal pain with $26(86.7 \%)$ cases, followed by 23 $(76.7 \%)$ cases of weight loss, $20(66.7 \%)$ cases of anorexia and $11(36.7 \%)$ cases of altered bowel habit. In the older group, abdominal pain and per rectal bleeding were the most reported complaint with $24(80 \%)$ and $23(76.7 \%)$ cases respectively, followed by 21 (70\%) cases of weight loss and anorexia each. If we compare the two groups, the older group frequently complained of $P R$ bleeding $(P=0.008)$ while the younger group mostly complained for altered bowel habit $(P<0.001)$ (Table 2).

\begin{tabular}{|c|c|c|c|c|}
\hline \multirow{2}{*}{ Site } & \multicolumn{2}{|c|}{ Group } & \multirow{2}{*}{$\chi^{2}$} & \multirow{2}{*}{$\begin{array}{c}P \\
\text { value }\end{array}$} \\
\hline & $\leq 40$ years & $>40$ years & & \\
\hline Rectum & $11(36.7 \%)$ & $\begin{array}{c}17 \\
(56.7 \%)\end{array}$ & 2.411 & 0.121 \\
\hline $\begin{array}{l}\text { Rectosigmoid } \\
\text { junction }\end{array}$ & $4(13.3 \%)$ & $1(3.3 \%)$ & 0.873 & 0.35 \\
\hline $\begin{array}{l}\text { Sigmoid } \\
\text { colon }\end{array}$ & & $2(6.7 \%)$ & 0.517 & 0.15 \\
\hline $\begin{array}{l}\text { Descending } \\
\text { colon }\end{array}$ & $1(3.3 \%)$ & - & & 1 \\
\hline $\begin{array}{l}\text { Splenic } \\
\text { Flexure }\end{array}$ & $1(3.3 \%)$ & & & 1 \\
\hline $\begin{array}{l}\text { Transverse } \\
\text { colon }\end{array}$ & $2(6.7 \%)$ & $2(6.7 \%)$ & & 1 \\
\hline $\begin{array}{l}\text { Hepatic } \\
\text { Flexure }\end{array}$ & $1(3.3 \%)$ & $2(6.7 \%)$ & & 1 \\
\hline $\begin{array}{l}\text { Ascending } \\
\text { colon }\end{array}$ & $7(23.3 \%)$ & $4(13.3 \%)$ & 1.002 & 0.317 \\
\hline Caecum & $3(10 \%)$ & $\begin{array}{l}2 \\
(6.7 \%)\end{array}$ & & 1 \\
\hline
\end{tabular}


between the two age groups. The most common sites for cancer occurrence was the rectum. In the younger group, tumor locations were varied but were mostly located in the rectum with $11(36.7 \%)$ cases, followed $7(23.3 \%)$ cases in the ascending colon, $4(13.3 \%)$ cases in the rectosigmoid junction, $3(10 \%)$ cases in the caecum, $2(6.7 \%)$ cases in the transverse colon and hepatic flexure, splenic flexure, and descending colon were all accounted to have $1(3.3 \%)$ case each site. The tumor in older group located mostly in the rectum i.e $17(56.7 \%)$ of all cases followed by 4 (13.3\%) cases in the ascending colon, and $2(6.7 \%)$ cases each in the caecum, transverse colon and hepatic flexure and $1(3.3 \%)$ case in the rectosigmoid junction. There was no tumor found in splenic flexure, and descending colon in this group (Table 3 ).

\begin{tabular}{|c|c|c|c|c|}
\hline \multirow{2}{*}{$\begin{array}{l}\text { Histopathological_ } \\
\text { examinations }\end{array}$} & \multicolumn{2}{|c|}{ Group } & \multirow[b]{2}{*}{$\chi^{2}$} & \multirow{2}{*}{$P$ value } \\
\hline & $\leq 40$ & $>40$ & & \\
\hline $\begin{array}{l}\text { Well differentiated } \\
\text { Adeno Carcinoma }\end{array}$ & $\begin{array}{c}14 \\
(46.7 \%)\end{array}$ & $\begin{array}{c}11 \\
(36.7 \%)\end{array}$ & 0.617 & 0.432 \\
\hline $\begin{array}{l}\text { Moderately } \\
\text { differentiated } \\
\text { Adeno Carcinoma }\end{array}$ & $9(30.0 \%)$ & $\begin{array}{c}13 \\
(43.3 \%)\end{array}$ & - & 1 \\
\hline $\begin{array}{l}\text { Poorly } \\
\text { differentiated } \\
\text { Adeno Carcinoma }\end{array}$ & $3(10 \%)$ & $5(16.7 \%)$ & 0.144 & 0.704 \\
\hline Signet rings cell & $1(3.3 \%)$ & - & - & 1 \\
\hline $\begin{array}{l}\text { Mucinous } \\
\text { Adenocarcinoma }\end{array}$ & $1(3.3 \%)$ & $1(3.3 \%)$ & & 1 \\
\hline $\begin{array}{l}\text { Non- Hodgkin } \\
\text { Lymphoma }\end{array}$ & $2(6.7 \%)$ & - & 0.517 & 0.472 \\
\hline
\end{tabular}

Adenocarcinoma is the dominant type in the two groups with $26(86.7 \%)$ cases in younger group and 29 $(96.7 \%)$ cases in older group. There were no significant differences in the incidence of adeno carcinoma, signet rings cell, mucinous carcinoma, non-Hodgkin Iymphoma. On further analysis, histologic grade comparison in adenocarcinoma group did not show significant difference between well, moderately and poorly differentiated carcinoma between younger group and older group $(\chi 2=0.617,0,0.144$ and $P=0.432,1$ and 0.472 respectively) (Table 4$)$.

\begin{tabular}{|llll|}
\hline \multicolumn{4}{|l}{ Table 5. Comparison of Hemoglobin at the time of } \\
admission. \\
\hline Group & Hemoglobin & P value \\
& Mean & SD & \\
$>40$ Years & 9.86 & 2.15 & 0.541 \\
$\leq 40$ Years & 10.16 & 1.59 & \\
\hline
\end{tabular}

Comparison of hemoglobin ( $\mathrm{Hb}$ ) level at admission between young and older group was not significantly different $(P=0.541)$. Mean $\mathrm{Hb}$ in younger group was
$10.16 \pm 1.59 \mathrm{~g} \%$ while in the older group mean $\mathrm{Hb}$ level was $9.86 \pm 2.15 \mathrm{~g} \%$ (Table 5 ).

\begin{tabular}{|c|c|c|c|c|}
\hline \multirow{2}{*}{ CEA group } & \multicolumn{2}{|c|}{ Group } & \multirow{2}{*}{$\chi^{2}$} & \multirow{2}{*}{ Pvalue } \\
\hline & $\leq 40$ Years & $>40$ Years & & \\
\hline$\leq 5 \mathrm{ng} / \mathrm{ml}$ & $6(20 \%)$ & 5 (17.9\%) & \multirow{2}{*}{0.043} & \multirow{2}{*}{0.835} \\
\hline$>5 \mathrm{ng} / \mathrm{ml}$ & $24(80 \%)$ & $23(82.1 \%)$ & & \\
\hline
\end{tabular}

From carcino-embryonic antigen (CEA) investigation during hospitalization we have collected data from 30 patients in younger group and only 28 patients in older group. The comparison of data with CEA level did not show any significant difference $(P=0.0835)$ (Table 6). The cutoff value of CEA was set at $5 \mathrm{ng} / \mathrm{ml}$.

\section{DISCUSSION}

Little is known about colorectal cancer in young age group and the behavior, clinical characteristics and prognosis of such tumors continue to be debated. Previous studies had shown some controversies on the differences in clinical characteristics and histopathologic types of CRC in different age groups. An aggressive behavior is a frequently cited characteristic of CRC in younger patients. ${ }^{6,7}$ In our study, colorectal cancer at younger ages showed similar clinical features to those of older patients except altered bowel habit was more common in younger patients while per rectal bleeding was more common in older patients which is contradiction to the study done by Nurdjanah $\mathrm{S}$ et $\mathrm{al}^{8}{ }^{8}$ which showed hematochezia was more common in young group and altered defecation pattern were the most reported complaint in the older group.

Recently, Al Jaberi et al, in comparative study of two groups (under 40 and more than 40 years old) had found that young age had more advanced staging at the time of diagnosis, and greater proportion of mucinous carcinoma and signet ring cell carcinoma. ${ }^{9}$ This result was contradictory with study of Bosola et al, who found no significant difference in stage at time of diagnosis between patients whose age under 40 years and the older ones. ${ }^{10}$ However, in our study, in both groups, adenocarcinoma was predominant lesion which is similar to the study done by Nurdjanah $\mathrm{S}$ et al. who also showed adenocarcinoma was dominant in the two groups.

In our study, the most common site of lesion was rectum in both the group followed by ascending colon. We considered caecum, ascending colon, hepatic flexure and transverse colon as proximal colon and splenic flexure, descending colon, sigmoid colon, rectosigmoid junction and rectum as distal colon. In younger patients, $43.4 \% \%$ and $56.6 \%$ of cases had lesion in 
proximal colon and distal colon. In patients aged above 40 years, $33.3 \%$ and $66.7 \%$ had lesions in proximal colon and distal colon. This was in concordance with the study done by Fazeli et al which showed the tumor site location was almost the same between two age groups. ${ }^{11}$ Similar studies done in Sri Lanka, Singapore and Egypt showed no significant difference in the tumor location of colorectal cancer in both the age groups. ${ }^{6,12,13}$ This finding is in contradiction to the Western literature, that incidence of $\mathrm{CRC}$ is more towards the proximal colon. ${ }^{14}$

In our study, there is no significant difference in CEA level and $\mathrm{Hb}$ level which is similar to the study done by Nurdjanah $\mathrm{S}$ et al, ${ }^{9}$ which also showed no significant difference in patients less than 40 years old compare to those in older age in CEA level and $\mathrm{Hb}$ level.

The limitation of the study is small sample size and single centered.

\section{CONCLUSIONS}

This study showed no statistical significant difference of colorectal cancer which occurred in patients $\leq 40$ years old compared to patients above the age of 40 years observed from histologic type and grade at time of diagnosis. The tumor site of colorectal cancer in both groups was found to be in the rectum with the chief complaint of altered bowel habit in younger patients and per rectal bleeding mostly in older patients.

Extra attention should be given to those patients with altered bowel habit, anemia, anorexia and loss of weight in the appropriate clinical context. The disease can present at a relatively young age and thus young patients with the right clinical picture should be investigated just as thoroughly as older patients.

\section{Conflict of Interest: None.}

\section{REFERENCES}

1. Ferlay J, Shin H, Bray F, Forman D, Mathers C, Parkin DM. Estimates of worldwide burden of cancer in 2008: GLOBOCAN 2008. Int J Cancer. 2010; 127:2893-917. [PubMed |DOI | Full Text]

2. Hamilton SR, Bosman FT, Boffetta P, et al. Carcinoma of the colon and rectum. WHO Classification of Tumors of the Digestive System 4th ed. 2010; p. 134-46.

3. Pradhananga KK, Baral M, Shrestha BM. Multi-institution hospital-based cancer incidence data for Nepal: an initial report. Asian Pac J Cancer Prev. 2009 Apr-Jun;10(2):259-62. [PubMed |Full Text]

4. Kansakar P, Singh Y. Changing trends of colorectal carcinoma in Nepalese young adults. Asian Pac J Cancer Prev. 2012;13(7):3209-12. [PubMed | Full Text]

5. Singh Y, Vaidya P, Hemandas AK, Singh KP. Colorectal carcinoma in Nepalese young adults: presentation and outcome. Gan To Kagaku Ryoho. 2002 Feb;29(1): 223-29. [PubMed]

6. De silva MV, Fernando MS, Fernando . Comparison of some clinical and histological features of colorectal carcinoma occurring in patients below and above 40yrs. Ceylon Med J. 2000 Dec;45(4):166-8. [PubMed]

7. Mitry E, Benhamiche AM, Jouve JL, et al. Colorectal adenocarcinoma in patients under 45 years of age: comparison with older patients in a well-defined French population. Dis Colon Rectum. 2001 Mar; 44:380-7. [PubMed]
8. Nurdjanah S, Taroeno S, Bayupurnama P, Maduseno S, Ratnasari N. Colorectal cancer in young patient: a distinguished disease entity? Indonesian J Gastroenterol Hepatol Digest Endosc. 2005; 6:37-41. [Full Text]

9. Al-Jaberi TM, Yaghan RJ, El-Heis HA. Colorectal cancer in young patients under 40 years of age. Comparison with old patients in a well-defined Jordanian population. Saudi Med J. 2003; 8:871-4. [PubMed]

10. Bossola M, Sofo L, Ratto C, et al. Colorectal cancer in patients 40 years of age and younger . Itali J Surg Sci. 1989;19(4):361-7. [PubMed]

11. Fazeli MS, Adel MG, Lebaschi AH. Colorectal carcinoma: a retrospective, descriptive study of age, gender, subsite, stage and differentiation in Iran from 1995 to 2001 as observed in Tehran University. Dis Colon Rectum. 2007 Jul;50(7):990. [PubMed]

12. Gupta S, Bhattacharya D, Acharya AN, Majumdar S, Ranjan P, Das S. Colorectal cancer in young adults: a retrospective study on Indian Patients: 2000-2008. Colorectal Dis. 2010 Oct;12(10):e 182-9. [PubMed | DOI | Full Text ]

13. Soliman AS, Bondy ML, Levin B, et al. Colorectal cancer in Egyptian patients under 40 yrs of age. Int J Cancer. 1997;71:26-30. [PubMed | DOI | Full Text ]

14. Wu X, Chen VW, Martin J, et al. Subsite-specific colorectal cancer incidence rates and stage distributions among Asians and Pacific Islanders in the United states, 1995 to 1999. Cancer PubMed Epidemiol Biomarkers Prev. 2004 Jul;13(7):1215-22 . [PubMed | Full Text] 